\title{
Nutrient sensitivity of gastric emptying of digesta in the preruminant calf
}

\author{
BY J. W. SISSONS \\ AFRC Institute for Grassland and Animal Production, Shinfield, Reading RG29AQ \\ AND F. R. BELL, \\ Department of Physiology \& Biochemistry, University of Reading, Whiteknights, \\ Reading RG6 $2 \mathrm{AJ}$ \\ AND C. L. GIRARD, \\ Station de Recherche, Lennoxville, Quebec JIM 1Z3, Canada
}

AND J. A. H. WASS

St Bartholomew's Hospital, London EC1A $7 B E$

(Received 1 April 1987 - Accepted 9 November 1987)

\begin{abstract}
1. Studies of gastric function were made in preruminant calves fitted with a single abomasal cannula, re-entrant cannulas in the duodenum close to the pylorus and recording electrodes on the pyloric antrum and proximal duodenum.

2. Simultaneous measurements were made of gastric emptying of a saline ( $9 \mathrm{~g}$ sodium chloride/l) meal, myoelectric activity of antral muscle and plasma concentration of somatostatin in jugular blood whilst infusing the duodenum with different solutions. The duodenal infusates were isotonic sodium bicarbonate (300 mosmol/ $\mathrm{kg})$, hyperosmolar solutions of $\mathrm{NaCl}(1000 \mathrm{mosmol} / \mathrm{kg})$, sodium carbonate $(500 \mathrm{mosmol} / \mathrm{kg})$, sucrose $(1000$ mosmol $/ \mathrm{kg}$ ), $41 \mathrm{~g}$ emulsified butterfat $/ \mathrm{kg}$ or $60 \mathrm{~mm}$-hydrochloric acid.

3. Infusing the duodenum with isotonic $\mathrm{NaHCO}_{3}$ stimulated intense myoelectric activity of the antral smooth muscie and rapid emptying of the test meal. In contrast, infusions of $60 \mathrm{~mm}-\mathrm{HCl}$ reduced antral motility and inhibited gastric emptying of digesta. This inhibitory response to $\mathrm{HCl}$ infusion was related to a significant $(P<0.05)$ increase of somatostatin in peripheral venous blood.

4. The $\mathrm{Na}_{2} \mathrm{CO}_{3}$ infusate, like $\mathrm{HCl}$, inhibited gastric motor activity and digesta emptying, but the concentration of circulating somatostatin was only slightly elevated above pre-infusion levels.

5. Compared with the effects of infusing $\mathrm{HCl}$, infusions of emulsified butterfat or hyperosmolar $\mathrm{NaCl}$ and sucrose induced a greater intensity of antral motor activity and faster outflow of gastric effluent, aithough not to the same extent as with isotonic $\mathrm{NaHCO}_{3}$. However, as with isotonic $\mathrm{NaHCO}_{3}$, these infusates did not evoke the release of somatostatin.

6. The results support the concept of duodenal receptors which, in response to a variety of stimuli in gastric chyme, modulate stomach emptying of digesta through actions on contractile processes of antral smooth muscle. Activation of such receptors by fat or osmotic stimuli, both ionic and non-ionic, do not appear to involve the release of somatostatin. However, the hormone appears to have an entero-gastrone role in mediating the inhibitory action of $\mathrm{HCl}$ on gastric motor function.
\end{abstract}

Milk-substitute diets for calves are based mainly on nutritional requirements of the growing animal, but without consideration of effects that diet composition might have on digestive function. It is, however, well established that some ingredients, such as fat, lactose and casein, can modulate processes which regulate the outflow of digesta from the abomasum to the duodenum (Smith \& Sissons, 1975; Bell \& McLeay, 1978) and this, in turn, may affect nutrient utilization. For example, studies in experimental calves given liquid feeds based on milk or soya-bean protein showed that the rate of digesta passage through the small intestine was critically related to the absorption of nitrogenous constituents (Sissons \& Smith, 1976).

A mechanism controlling abomasal (gastric) emptying in the calf responds to the 
composition of chyme in the proximal small intestine (Bell \& Razig, 1973; Smith \& Sissons, 1975). Early studies of this reflex mechanism in the dog demonstrated an influence of osmotic pressure of stomach contents and led to the idea of 'osmo-receptors' in the duodenal wall (Carnot \& Chassevant, 1905). However, studies in cannulated calves indicated that another important factor governing the outflow of gastric effluent arises from an effect of hydrochloric acid (Bell \& Mostaghni, 1975). Bell et al. (1981 b) reported that infusions with high-proton activity totally blocked abomasal digesta outflow, whereas lowproton solutions, for example, sodium bicarbonate, led to a rapid output of effluent.

The mechanism of interaction between the duodenal receptor and gastric effector is not well understood. It has been reported that the inhibitory effect of $\mathrm{HCl}$ on the duodenum in the dog is related to an increase in circulating 5-hydroxytryptamine (Jaffe et al. 1977). This was not confirmed in the calf where circulating somatostatin, probably released from ' $D$ ' cells in the intestinal mucosa, was positively linked to depolarization of antral smooth muscle and complete cessation of digesta outflow from the abomasum (Bell et al. $1981 a, c)$.

Besides osmo- and chemo-receptors, other duodenal receptors responsive to milk protein and fat may also play a part in the reflex control of abomasal emptying (Smith $\&$ Sissons, 1975; Bell \& McLeay, 1978; Bush et al. 1963). In the present work we have examined a variety of stimuli to determine if, like $\mathrm{HCl}$, they inhibit abomasal emptying of digesta by the same mechanism of antral muscle depolarization and whether this also involves the release of somatostatin.

\section{METHODS \\ Animals and feeding}

Six Friesian bull calves fed on cows' milk were used in the experiments. At 3 weeks of age they were anaesthetized with a halothane-oxygen mixture and provided with a cannula in the corpus of the abomasum and re-entrant cannulas in the proximal duodenum as described previously (Bell \& Mostaghni, 1975). In addition groups of stainless steel recording electrodes (Cooner Sales Co. Inc., California) were implanted in the antral muscle, $50 \mathrm{~mm}$ proximal to the pylorus, and on the duodenum, immediately distal to the re-entrant cannulas, as described by Ruckebusch (1970).

Experiments were made 3 weeks after surgery. They were carried out before giving a morning feed and at intervals of 2-3 d. The abomasum was washed out with normal saline $(9 \mathrm{~g}$ sodium chloride/l) immediately before an experiment. The infusate was introduced into the duodenum through the distal arm of the re-entrant cannulas at $10 \mathrm{ml} / \mathrm{min}$. This was maintained for a period beginning $5 \mathrm{~min}$ before and ending $50 \mathrm{~min}$ after placing a standard liquid meal of 1.5 litres normal saline into the abomasum. Effluent emptying from the abomasum was collected from the outgoing limb of the duodenal cannulas at intervals of $15 \mathrm{~min}$ from introduction of the test meal. These procedures have been described elsewhere (Bell \& Mostaghni, 1975).

Collections of digesta were made whilst recording action potentials from the wire electrodes. The electrical activity was displayed using a Grass model 7 polygraph with AC pre-amplifiers linked to a summating integrator (Grass Instruments, Mass.). The polygraph trace of action potentials and corresponding integration shown in Fig. 1 exemplifies the patterns of myoelectric activity recorded from the antrum. The rhythmic bursts of activity are the basis of regular contractions of gastric smooth muscle (Bell, 1980).

The duodenal infusates were solutions of isotonic $\mathrm{NaHCO}_{3}$ (300 mosmol $/ \mathrm{kg}$ ), hyperosmolar sodium carbonate $(500 \mathrm{mosmol} / \mathrm{kg}), \mathrm{NaCl}(1000 \mathrm{mosmol} / \mathrm{kg})$, sucrose (1000 mosmol $/ \mathrm{kg}), 60 \mathrm{~mm}-\mathrm{HCl}$ and emulsified butterfat $(41 \mathrm{~g} / \mathrm{kg})$. The butterfat emulsion 
(a)

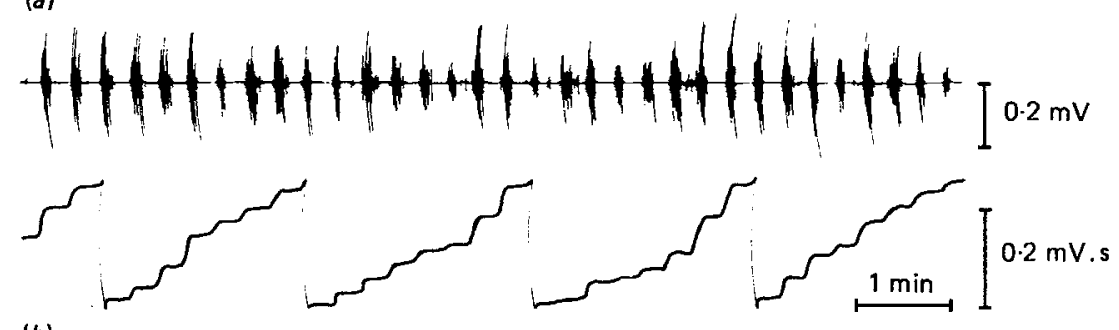

(b)
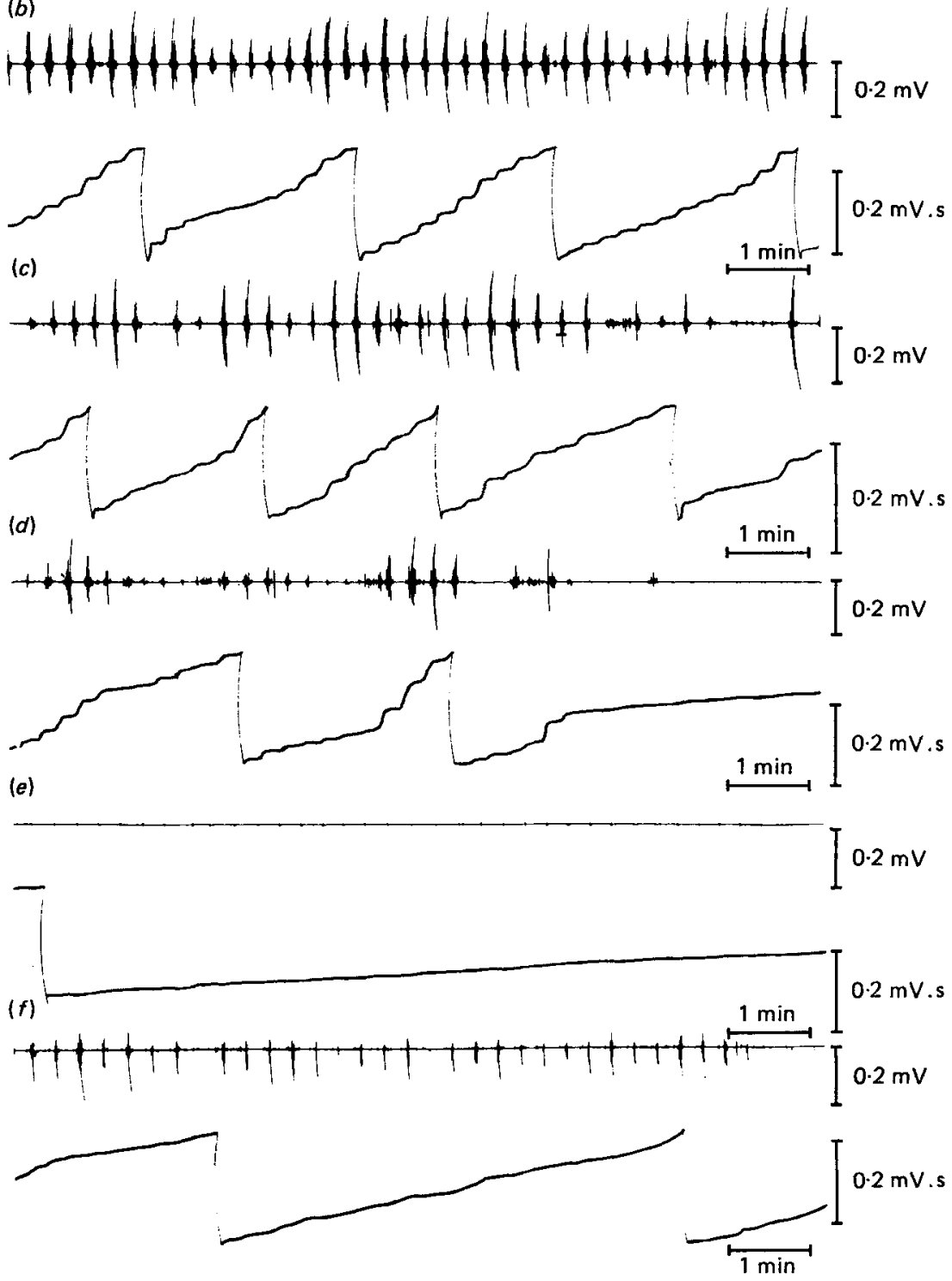

Fig. 1. Typical recordings of myoelectric activity of the antrum showing recurrent bursts of rapidly oscillating potentials (upper trace) and of summated activity after passing the electrical signals through an integrator (lower trace). These recordings were made about $15 \mathrm{~min}$ after placing a test meal of 1.5 litres saline ( $9 \mathrm{~g}$ sodium chloride/l) into the abomasum and during infusion of the duodenum with $(a)$ 300 mosmol sodium bicarbonate $/ \mathrm{kg}$, (b) $1000 \mathrm{mosmol} \mathrm{NaCl} / \mathrm{kg}$, (c) 1000 mosmol sucrose $/ \mathrm{kg},(d) 41 \mathrm{~g}$ butterfat $/ \mathrm{kg}$, (e) 500 mosmol sodium carbonate $/ \mathrm{kg}$ or $(f) 60 \mathrm{~mm}$-hydrochloric acid. 
was prepared by homogenizing double cream (50\% fat) with distilled water at $39^{\circ}$ for 20 min. During infusion, this mixture was gently agitated with a magnetic stirrer to prevent separation of the fat from the aqueous phase. The infusates were administered in a random order according to a Latin-square design.

\section{Blood sampling and radioimmunoassay}

Blood taken by venepuncture of the jugular vein was placed into tubes containing lithium heparin and $10000 \mathrm{kIU}$ aprotinin $/ 10 \mathrm{ml}$ sample. After centrifugation at $4^{\circ}$ plasma samples were stored at $-20^{\circ}$. Immunoreactive somatostatin was measured by radioimmunoassay according to the method of Penman et al. (1979).

\section{Osmolality}

Osmolality of the infusates was determined using an apparatus (Model L, Advanced Instruments Inc., Mass.) for measuring freezing-point depression.

\section{Statistical analysis}

The significance of treatment differences in flow of gastric digesta, integrated myoelectric activity and plasma concentration of somatostatin was examined by analysis of variance. The significance of differences between values of somatostatin concentration of paired blood samples taken before and after duodenal infusion was examined using Student's $t$ test. An assessment of the relation between amounts of digesta leaving the abomasum and integrated myoelectric activity of the antrum during successive $15 \mathrm{~min}$ periods after giving the test meal was made by regression analysis of the combined values for all treatments.

\section{RESULTS}

The effect of different duodenal infusions on gastric motility and emptying of digesta Introduction of the test meal usually led to an increase in the frequency and intensity of the antral spike bursts compared with activity observed whilst the abomasum was empty. This response to the meal lasted for about 2-3 min. Thereafter these motor events occurred at fairly regular intervals, but variations in the duration and amplitude of the spike bursts were induced according to the nature of the duodenal infusates (Fig. 1). The recordings of spike bursts and corresponding integrated measurements show that the intensity of the oscillating potentials was considerably elevated during infusions of isotonic $\mathrm{NaHCO}_{3}$ compared with the electrical activity when $60 \mathrm{~mm}-\mathrm{HCl}$ was introduced into the duodenum. In contrast, spike bursts were absent from the recordings for 500 mosmol $\mathrm{Na}_{2} \mathrm{CO}_{3} / \mathrm{kg}$. Infusing emulsified butterfat led to spike bursts of intermediate intensity compared with the $\mathrm{HCl}$ and $\mathrm{NaHCO}_{3}$ infusates, whereas hyperosmolar $(1000 \mathrm{mosmol} / \mathrm{kg})$ solutions of $\mathrm{NaCl}$ and sucrose showed patterns similar to that for $\mathrm{NaHCO}_{3}$ (Fig. 1).

Results given in Tables 1 and 2 quantify the effects of the different infusates on the intensity of spike activity and on the passage of gastric effluent respectively. During the infusion of isotonic $\mathrm{NaHCO}_{3}$ into the duodenum, outflow of the test meal from the abomasum was rapid; indeed most of the 1.5 litre meal had left the abomasum within $30 \mathrm{~min}$ (Table 2). This rapid outflow of digesta was in response to intense activity of the antral muscle (Table 1 and Fig. 1). In contrast, infusing $60 \mathrm{~mm}-\mathrm{HCl}$ into the duodenum slowed the passage of the test meal such that by $45 \mathrm{~min}$ after its introduction less than 0.5 litres had entered the duodenal cannula. It is evident from a typical electromyographic recording (Fig. 1) that antral spike activity was markedly depressed by the acidification of the duodenum. Comparisons of the effects of these two infusates on abomasal function shown in Tables 1 and 2 indicate significant differences $(P<0.05)$ between values of digesta 
Table 1. Mean relative integrated myoelectric activity $(\mathrm{mV} . \mathrm{s})^{*}$ of the pyloric antrum of preruminant calves ( $\mathrm{n} 6$ ) during successive 15 min periods after placing a test meal into the abomasum and whilst infusing the duodenum with different solutions $\dagger$

\begin{tabular}{llrrrr}
\hline \hline Duodenal infusate & \multicolumn{3}{c}{$\begin{array}{c}\text { Osmolality } \\
\text { (mosmol/kg) }\end{array}$} & \multicolumn{3}{c}{$\begin{array}{c}\text { Period of time (min) } \\
\text { after introduction } \\
\text { of the test meal }\end{array}$} \\
\cline { 3 - 6 } & 300 & 310 & $15-30$ & $30-45$ \\
\hline Sodium bicarbonate & 1000 & 236 & 137 & 120 \\
Sucrose & 1000 & 188 & 132 & 142 \\
Butterfat & 10 & 194 & 105 & 125 \\
Sodium carbonate & 500 & 24 & 32 & 29 \\
Hydrochloric acid & 60 & 93 & 77 & 73 \\
LSD & - & 106 & 78 & 99 \\
\hline
\end{tabular}

LSD, least significant difference $(P=0.05)$ based on the error mean square with $19 \mathrm{df}$ in the analysis of variance.

* An internal standard signal of $0.2 \mathrm{mV}$ from the AC amplifier set at 10-35 $\mathrm{HZ}(-3 \mathrm{~dB})$ was used to calibrate the summating integrator.

$\dagger$ The test meal was 1.5 litres isotonic saline $(9 \mathrm{~g} \mathrm{NaCl} / 1)$ at $\mathrm{pH} 6.0$. The duodenal infusates were administered at a rate of $10 \mathrm{ml} / \mathrm{min}$ for a period beginning $5 \mathrm{~min}$ before and ending $50 \mathrm{~min}$ after placing the test meal into the abomasum.

Table 2. Mean amount $(l)$ of digesta leaving the stomach of preruminant calves (n 6 ) during successive $15 \mathrm{~min}$ periods after placing a test meal into the abomasum and whilst infusing the duodenum with different solutions $\dagger$

\begin{tabular}{lllll}
\hline Duodenal infusate & $\begin{array}{c}\text { Osmolality } \\
\text { (mosmol/kg) }\end{array}$ & $\begin{array}{c}\text { Period of time (min) } \\
\text { after introduction } \\
\text { of the test meal }\end{array}$ \\
\hline Sodium bicarbonate & 300 & 1.07 & $15-30$ & $30-45$ \\
Sodium chloride & 1000 & 0.89 & 0.36 & 0.09 \\
Sucrose & 1000 & 0.67 & 0.23 & 0.17 \\
Butterfat & 10 & 0.72 & 0.12 & 0.09 \\
Sodium carbonate & 500 & 0.06 & 0.00 & 0.00 \\
Hydrochloric acid & 60 & 0.32 & 0.14 & 0.02 \\
LSD & - & 0.29 & 0.13 & 0.10 \\
\hline
\end{tabular}

LSD, least significant difference $(P=0.05)$ based on the error mean square with $19 \mathrm{df}$ in the analysis of variance.

$\uparrow$ The test meal was 1.5 litres isotonic saline $(9 \mathrm{~g} \mathrm{NaCl} / 1)$ at $\mathrm{pH} 6.0$. The duodenal infusates were administered at a rate of $10 \mathrm{ml} / \mathrm{min}$ for a period of $5 \mathrm{~min}$ before and ending $50 \mathrm{~min}$ after placing the test meal into the abomasum.

outflow and between corresponding measurements of integrated electrical activity recorded during the first $15 \mathrm{~min}$ of gastric emptying.

Results given in Tables 1 and 2 showing contrasting stimulatory and inhibitory effects of isotonic $\mathrm{NaHCO}_{3}$ and $60 \mathrm{~mm}-\mathrm{HCl}$ respectively on abomasal emptying of the test meal and antral motor activity are consistent with previous findings of Bell \& Grivel (1975). Consequently these infusates were used in the present experiments to provide a reference to the other solutions studied. Hypertonic $\mathrm{NaCl}$ and sucrose were used to provide 
Table 3. Mean plasma concentration $(\mathrm{pg} / \mathrm{ml})$ of immunoreactive somatostatin 5 min before, immediately before and at 15,35 and 55 min following commencement of infusion of the duodenum of preruminant calves ( $\mathrm{n} 6$ ) with different solutions*

\begin{tabular}{|c|c|c|c|c|c|c|}
\hline \multirow[b]{2}{*}{ Duodenal infusate } & \multirow{2}{*}{$\begin{array}{c}\text { Osmolality } \\
(\mathrm{mosmol} / \mathrm{kg})\end{array}$} & \multicolumn{5}{|c|}{$\begin{array}{l}\text { Time (min) of blood sample relative } \\
\text { to the start of duodenal infusion }\end{array}$} \\
\hline & & -5 & 0 & 15 & 35 & 55 \\
\hline Sodium bicarbonate & 300 & 103 & 81 & 101 & 86 & 77 \\
\hline Sodium chloride & 1000 & 112 & 117 & 100 & 93 & 95 \\
\hline Sucrose & 1000 & 94 & 82 & 98 & 101 & 83 \\
\hline Butterfat & 10 & 97 & 89 & 107 & 93 & 94 \\
\hline Sodium carbonate & 500 & 115 & 115 & 131 & 121 & 116 \\
\hline Hydrochloric acid & 60 & 122 & 96 & 164 & 168 & 113 \\
\hline LSD (df) & - & $40(19)$ & $31(16)$ & $53(16)$ & $50(19)$ & $40(19)$ \\
\hline
\end{tabular}

LSD, least significant difference $(P=0.05)$ based on the error mean square in the analysis of variance.

* The duodenal infusates were administered at a rate of $10 \mathrm{ml} / \mathrm{min}$ for a period beginning $5 \mathrm{~min}$ before and ending $50 \mathrm{~min}$ after placing a test meal into the abomasum. The test meal was 1.5 litres isotonic saline $(9 \mathrm{~g} \mathrm{NaCl} / 1)$ at $\mathrm{pH} 6.0$.

stimulation of putative duodenal osmo-receptors to test the hypothesis of Hunt \& Knox (1968) that such receptors cause reflex inhibition of the antral pump. The myoelectric activities of the antrum during duodenal infusion of $1000 \mathrm{mosmol} \mathrm{NaCl}$ or sucrose $/ \mathrm{kg}$ were very similar (Table 2 and Fig. 1), suggesting that the effect was osmotic and not ionic or molecular. On the other hand, the emulsified butterfat which was hypo-osmolar induced a similar degree of depolarization in antral myoelectric activity as the $\mathrm{NaCl}$ and sucrose infusions. However, these depolarizing effects on antral smooth muscle were relatively minor compared with the influence of 500 mosmol $\mathrm{Na}_{2} \mathrm{CO}_{3} / \mathrm{kg}$. This infusate inhibited abomasal motor activity to an even greater extent than $60 \mathrm{mM}-\mathrm{HCl}$. Indeed, the $\mathrm{Na}_{2} \mathrm{CO}_{3}$ solution completely depolarized antral smooth muscle (Fig. 1) such that little or no digesta passed from the abomasum whilst $\mathrm{Na}_{2} \mathrm{CO}_{3}$ infusion into the small gut was maintained (see Table 2).

Regression analysis of the relation between the corresponding mean values of gastric myoelectric activity (Table 1) and digesta outflow (Table 2) indicated that the intensity of antral motor events recorded between $0-15$ and 15-30 min after giving the test meal was significantly correlated with the amount of effluent emptied from the calf stomach; correlation coefficients for comparisons made during these two successive 15 min periods are $0.99(P<0.01)$ and $0.86(P<0.05)$ respectively. During the subsequent $15 \mathrm{~min}$ period of measurement of gastric function the broad relation between the effects on antral muscular activity of the different duodenal infusates remained unchanged (Table 1). However, at this time values of integrated myoelectric activity did not correlate with measurements of gastric digesta outflow, presumably because little of the test meal remained in the abomasum between 30 and 45 min after infusions of $\mathrm{NaHCO}_{3}$ or $\mathrm{NaCl}$ (Table 2).

\section{Effects of duodenal infusions on plasma somatostatin}

The genesis and effects of the different duodenal infusates on smooth muscle activity in the antrum are reflected in variations in somatostatin levels of peripheral blood. Only infusion of $\mathrm{Na}_{2} \mathrm{CO}_{3}$ and $\mathrm{HCl}$ resulted in a notable rise in somatostatin; compared with a preinfusion level of 98 (SE 10) $\mathrm{pg} / \mathrm{ml}$, the post-infusion concentration of somatostatin had by $15 \mathrm{~min}$ reached 131 (SE 18) and 164 (SE 30) pg/ml for these infusates respectively. This elevated level of somatostatin persisted until duodenal infusion was withdrawn. However, 
using a $t$ test to assess the significance of differences between values of paired samples, only treatment with $\mathrm{HCl}$ gave concentrations of somatostatin which were significantly different $(P<0.05)$ from pre- or post-infusion levels. Results presented in Table 3 show that elevations in plasma somatostatin concentration during $\mathrm{HCl}$ infusion were significantly different $(P<0.05)$ from values obtained during infusion of $\mathrm{NaHCO}_{3}$ or $\mathrm{NaCl}$, butterfat and sucrose. Compared with isotonic $\mathrm{NaHCO}_{3}$, the inhibition of abomasal motor function induced by duodenal infusion of hyperosmolar sodium chloride or sucrose and non-ionic hypo-osmolar butterfat did not relate to any change in the concentration of circulating somatostatin.

\section{DISCUSSION}

Effective digestion of a meal in the stomach depends on adequate contractile activity of the muscle wall to break down food and at the same time to mix gastric contents with digestive enzymes. However, these motor processes must be regulated to minimize the premature passage of large quantities of undigested dietary components to the small intestine, otherwise digestive disorders may ensue (Shillam \& Roy, 1963). Studies in the pre-ruminant calf have shown that regulation of gastric emptying is mediated through mechanisms initiated in the anterior duodenum (Bell \& Razig, 1973). Indirect evidence supports the idea of duodenal receptors responding to variations in the physico-chemical nature of chyme entering the small gut and thereby monitoring the progress of gastric digestion (Hunt \& Knox, 1968).

Results presented here confirm that a variety of substances was able to modulate the rate of outflow of gastric digesta by acting through a putative system of duodenal receptors, although sensitivity of the reflex seemed to vary somewhat with the different infusates. Infusing solutions containing carbonate or hydrogen ions into the duodenum led to a marked suppression in intensity of myoelectric activity of the antrum and a slow rate of emptying of abomasal digesta, whereas feed-back responses arising from infusions of butterfat or hyperosmolar solutions of sucrose seemed to be less inhibiting to gastric function (see Tables 1 and 2). It is uncertain, however, whether the mechanism involves a single sensor or several receptors each having specificity for individual components of digesta. Nevertheless, the results suggest that alteration of diet composition could have an effect on the delivery of nutrients by the abomasum to the small intestine. For example, acidification of milk substitutes with organic acids has been claimed to improve growth performance of calves (Low, 1979). This treatment may increase the residence time of protein in the abomasum and thereby extend the phase of gastric proteolysis. In a recent electromyographic study of abomasal motility, we observed a reduction in the amplitude and duration of antral spike bursts in calves fed on an acidified, rather than a conventional, milk substitute (J. W. Sissons and C. Duvaux, unpublished observations).

The inhibition of antral motor responses of the abomasum following duodenal infusion of $60 \mathrm{mM}-\mathrm{HCl}$ was related to significant elevation in the level of circulating somatostatin (see Table 3). A similar response was also observed after an infusion of 500 mosmol $\mathrm{Na}_{2} \mathrm{CO}_{3} / \mathrm{kg}$. In the case of $\mathrm{HCl}$ its inhibitory action is probably mediated through a nonneural enterogastrone effect since in a previous study the ability of the $60 \mathrm{mM}-\mathrm{HCl}$ infusate to suppress myoelectric oscillations of antral smooth muscle cells was unimpaired by splanchnovagotomy, but associated with a significant increase in endogenous somatostatin (Bell et al. 1981 a). In similar experiments Bell et al. (1981 c) noted an immediate cessation of spike potentials shown on electromyographic recordings from the calf antrum after intravenous injection of synthetic somatostatin. These observations are in contrast to a report that in the rhesus monkey intravenous infusion of cyclic somatostatin did not alter motor performance of gastric muscle (Koerker \& Hansen, 1981), whilst in anaesthetized 
rats this treatment resulted in an increase in the rate of stomach emptying (Daumerie \& Henquin, 1982). However, more recently Barry et al. (1985) showed that continuous infusion of cyclic somatostatin into peripheral venous blood of sheep resulted in the accumulation of digesta in the abomasum and caecum, which agrees with our findings.

Although somatostatin has been localized by immunofluorescence in neural fibres of the myenteric plexus (Hokfelt et al. 1975; Costa et al. 1977), there is no evidence that the hormone acts directly on smooth muscle cells. Somatostatin has been found to reduce the amplitude of contractions of isolated segments of muscle taken from the ileum of the guinea-pig, but this was seemingly brought about by blockage in the release of acetylcholine, rather than antagonizing the action of the synaptic neurotransmitter (Guillemin, 1976; Furness \& Costa, 1979).

In the preruminant calf, somatostatin may not act alone, or indeed be directly involved, in inhibiting gastric motor activity in response to acidification of the duodenum, since under these conditions Bell \& Watson (1975) noted elevations in plasma concentrations of both secretin and pancreatic glucagon in venous blood. In further studies it was found that these peptides were capable of abolishing the action potentials of the pyloric antrum when they were administered by intravenous infusion (McLeay Bell, 1980). It is not known if they act on axons of gastric muscle.

Duodenal perfusates of the non-ionic substances, sucrose and fat, slowed the emptying of the test meal compared with the response to infusion of isotonic $\mathrm{NaHCO}_{3}(\mathrm{Table} 2)$. This implies that the ingredients of a milk-substitute diet supplying energy might be used to regulate abomasal emptying during a period shortly after feeding, when the hydrogen ion content of the gastric effluent is relatively low and the rate of digesta is fairly rapid (Smith \& Sissons, 1975). An examination of data from several studies of gastric emptying in man by Hunt \& Stubbs (1975) led these authors to propose that the degree of inhibition of digesta outflow is directly proportional to the combustible energy of the meal. However, this view was not supported by results of a study in the calf which dissociated the osmotic and energy effects of monosaccharides in duodenal infusates on abomasal emptying of a test meal (Bell \& Webber, 1979). In the present study, the basal level of endogenous somatostatin was unaffected (Table 3 ), suggesting that the inhibitory effects of fat and sucrose on gastric function did not act through stimulation of duodenal ' $D$ ' cells and the release of the inhibitory peptide into the circulation. Fat in the duodenum may have stimulated the release of cholecystokinin (Meyer \& Grossman, 1972) which in previous studies with the calf was shown to reduce the intensity of abomasal myoelectric potentials (McLeay \& Bell, 1980).

Infusion of the duodenum with 300 mosmol $\mathrm{NaHCO}_{3} / \mathrm{kg}$ induced relatively rapid emptying of the test meal and strong bursts of myoelectric activity on the antrum (see Fig. 1). These results are in agreement with earlier reports that isotonic $\mathrm{NaHCO}_{3}$ evokes a maximal response of duodenal receptors (Bell \& Grivel, 1975; Bell \& Mostaghni, 1975). Whether or not this strong muscular activity was induced through hormonal responses is unknown. Stimulatory effects on gastric emptying by $\mathrm{NaHCO}_{3}$ were reported by Bell et al . $(1981 a)$ to have been significantly reduced after vagotomy and that such denervation gave rise to a substantial increase in somatostatin concentration in jugular blood. This work suggests that inhibitory actions of somatostatin on motor function may be attenuated by activation of duodenal sensors which stimulate neural reflexes.

We found a significant relation between the intensity of myoelectric activity and the amounts of the test meal entering the duodenum at different times after abomasal infusion. In intact animals, however, other factors besides motility of the antrum may also influence gastric emptying of digesta. It is likely that outflow from the stomach would to some extent be influenced by the availability of space in the proximal duodenum. Also fluid passage 
from the abomasum sometimes occurs during persistent contractions of the fundus whilst antral muscle is quiescent (Bell \& Grivel, 1975).

In conclusion our results indicate that the duodenal reflex control of stomach emptying responds to a multiple of properties of effluent entering the small intestine. The mechanism is directed towards the modulation of antral motility. The active phase of gastric emptying of digesta is probably regulated by a neural reflex initiated mainly through duodenal osmoreceptors. When gastric emptying nears completion the hydrogen ion mass in the effluent becomes an important factor and on reaching the anterior duodenum it appears to activate the release of somatostatin which may be associated with the inhibition of gastric motility. However, the same hormone does not seem to be involved in the inhibitory response of gastric motility to non-ionic substances such as butterfat and sucrose. These findings suggest that alteration in the physical or chemical nature of a milk-substitute diet for calves may affect nutrient delivery from the abomasum to the small intestine.

The authors thank Mrs S. M. Banks and Mrs C. P. Chard for skilled assistance.

\section{REFERENCES}

Barry, T. N., Raichney, G. J. \& Redekopp, C. (1985). Australian Journal of Biological Sciences 38, 393-403.

Bell, F. R. (1980). In Digestive Physiology and Metabolism in Ruminants, pp. 81-100 [Y. Ruckebusch \& P. Thivend, editors]. Lancaster: MTP Press.

Bell, F. R., Green, A. R., Wass, J. A. H. \& Webber, D. E. (1981 a). Journal of Physiology 321, 603-610.

Bell, F. R. \& Grivel, M. L. (1975). Journal of Physiology 248, 377-391.

Bell, F. R. \& McLeay, L. M. (1978). Journal of Physiology 282, 51-57.

Bell, F. R. \& Mostaghni, K. (1975). Journal of Physiology 228, 499-512.

Bell, F. R., Nouri, M. \& Webber, D. E. (1981 b). Journal of Physiology 314, 331-341.

Bell, F. R. \& Razig, S. A. D. (1973). Journal of Physiology 228, 513-526.

Bell, F. R. \& Watson, D. J. (1975). In Proceedings of the Fifth International Symposium on Gastrointestinal Motility, Leuven, pp. 336-342. Belgium: Typoff Press.

Bell, F. R. \& Webber, D. E. (1979). Journal of Physiology 297, 379-385.

Bell, F. R., Webber, D. E., Wass, J. A. H., Rees, L. H., Evans, J., Morgan, L. M., Marks, V. \& Lewis, J. (1981 c). Journal of Endocrinology 89, 451-456.

Bush, L. J., Schuh, J. D., Tennille, N. B. \& Waller, G. R. (1963). Journal of Dairy Science 46, 703-709.

Carnot, P. \& Chassevant, A. (1905). Compte Rendu des Séances de la Société de Biologie 58, 173-176.

Costa, M., Patel, Y., Furness, J. B. \& Arimura, A. (1977). Neuroscience Letters 6, 215.

Daumerie, C. \& Henquin, J. C. (1982). Gut 23, 140-145.

Furness, J. B. \& Costa, M. (1979). European Journal of Pharmacology 56, 69-74.

Guillemin, R. (1976). Endocrinology 99, 1653-1654.

Hokfelt, T., Johansson, O., Efendic, S., Luft, R. \& Arimura, A. (1975). Experientia 3, 852.

Hunt, J. N. \& Knox, M. T. (1968). In Handbook of Physiology, section 6, vol. IV, pp. 1917-1935 [C. R. Code, editor]. Washington: American Physiological Society.

Hunt, J. N. \& Stubbs, D. R. (1975). Journal of Physiology 245, $209-225$.

Jaffe, B. M., Kopen, D. R. \& Lazan, D. W. (1977). Surgery 82, 156-163.

Koerker, D. J. \& Hansen, B. C. (1981). Metabolism 30, 335-339.

Low, B. (1979). Dairy Farmer June, 62-64.

McLeay, L. M. \& Bell, F. R. (1980). American Journal of Veterinary Research 41, 1590-1594.

Meyer, J. H. \& Grossman, M. I. (1972). In Gastrointestinal Hormones, pp. 43-55 [L. Demling, editor]. Stuttgart: Georg Thieme.

Penman, E., Wass, J. A. H., Lund, A., Lowry, P. J., Stewart, J., Dawson, A. M., Besser, G. M. \& Rees, L. H. (1979). Annals of Clinical Biochemistry 16, 15-25.

Ruckebusch, Y. (1970). Journal of Physiology 210, 857-882.

Shillam, K. W. G. \& Roy, J. H. B. (1963). British Journal of Nutrition 17, 171-181.

Sissons, J. W. \& Smith, R. H. (1976). British Journal of Nutrition 36, 421-438.

Smith, R. H. \& Sissons, J. W. (1975). British Journal of Nutrition 33, 329-349. 